University of Nebraska - Lincoln

DigitalCommons@University of Nebraska - Lincoln

Faculty Publications, Department of Child, Youth, and Family Studies

Child, Youth, and Family Studies, Department of

February 2004

\title{
Ngecha: A Kenyan village in a time of rapid social change
}

Carolyn P. Edwards

University of Nebraska-Lincoln, cedwards1@unl.edu

Follow this and additional works at: https://digitalcommons.unl.edu/famconfacpub

Part of the Family, Life Course, and Society Commons

Edwards, Carolyn P., "Ngecha: A Kenyan village in a time of rapid social change" (2004). Faculty Publications, Department of Child, Youth, and Family Studies. 25.

https://digitalcommons.unl.edu/famconfacpub/25

This Article is brought to you for free and open access by the Child, Youth, and Family Studies, Department of at DigitalCommons@University of Nebraska - Lincoln. It has been accepted for inclusion in Faculty Publications, Department of Child, Youth, and Family Studies by an authorized administrator of DigitalCommons@University of Nebraska - Lincoln. 

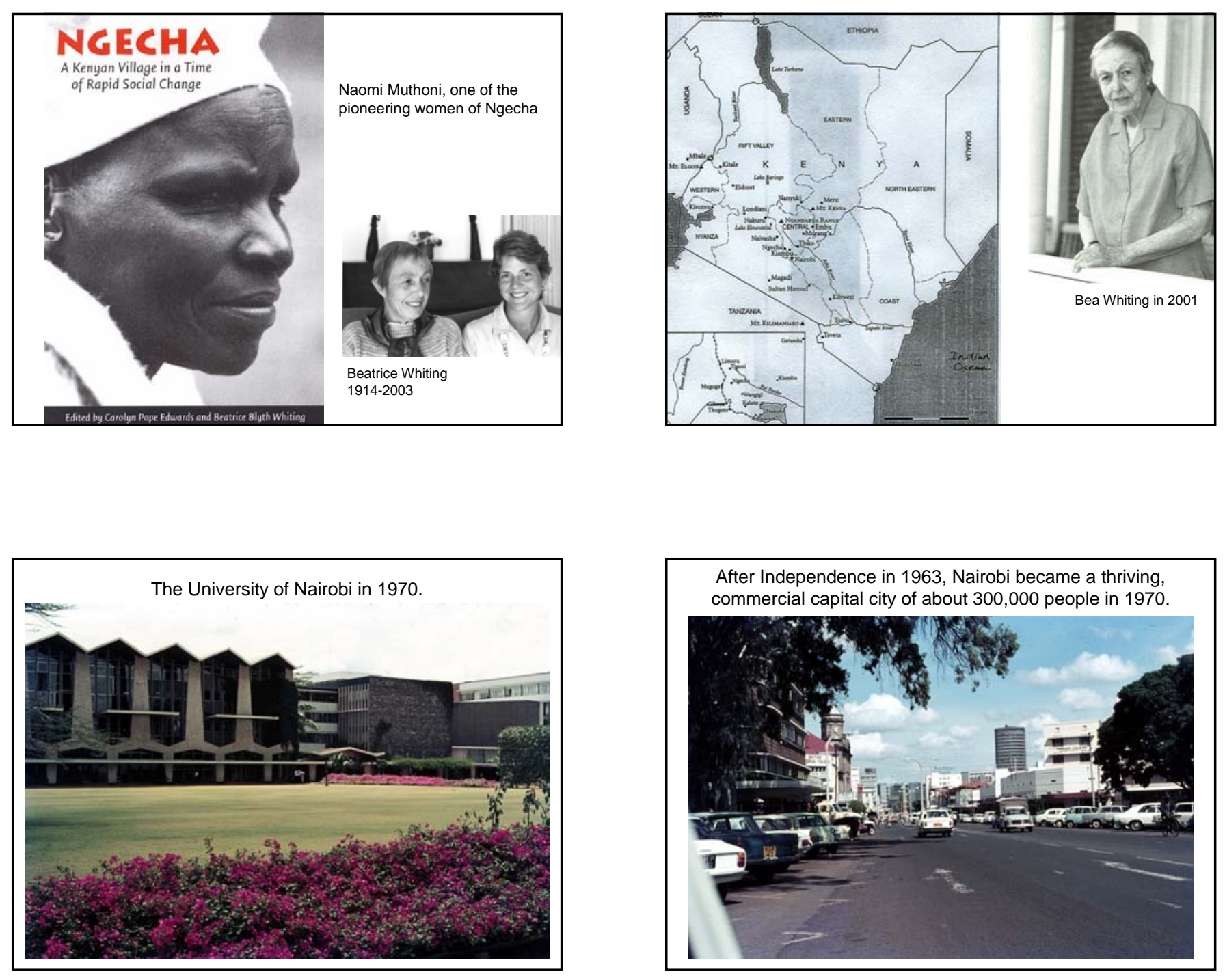

Many University of Nairobi students had been schooled in quiet, selective boarding secondary schools in rural areas.

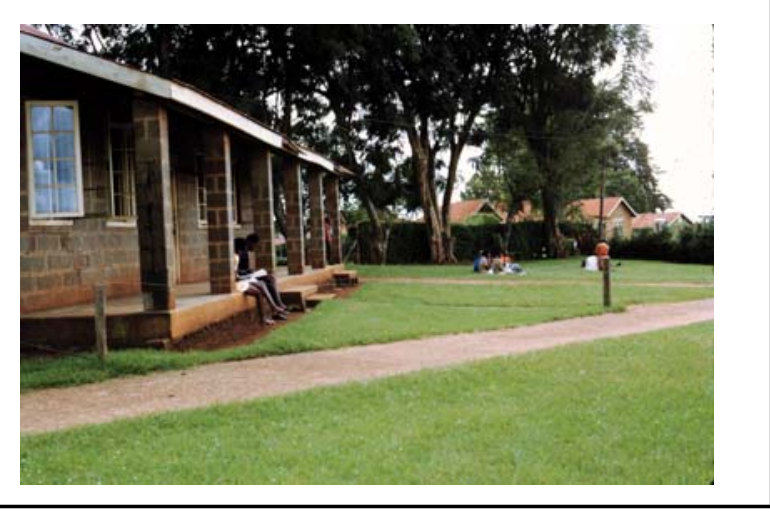

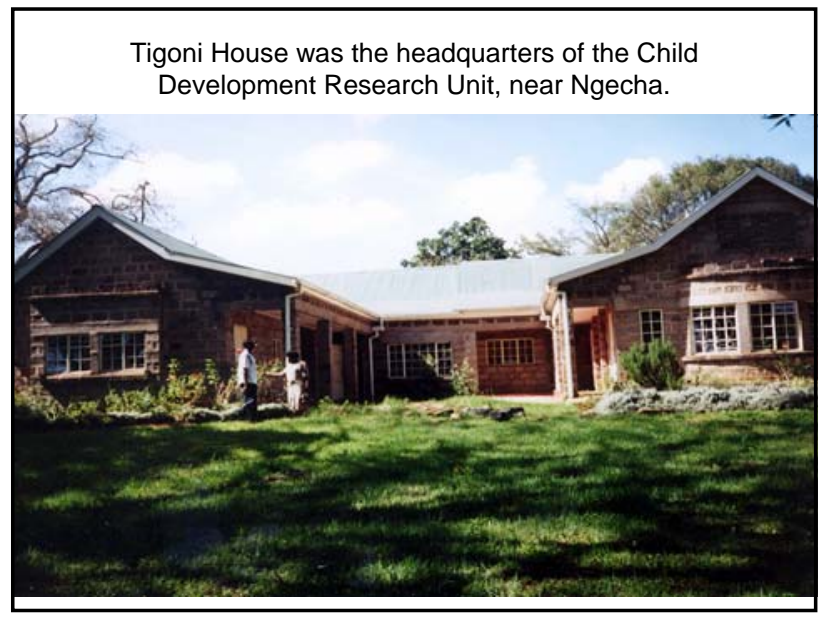



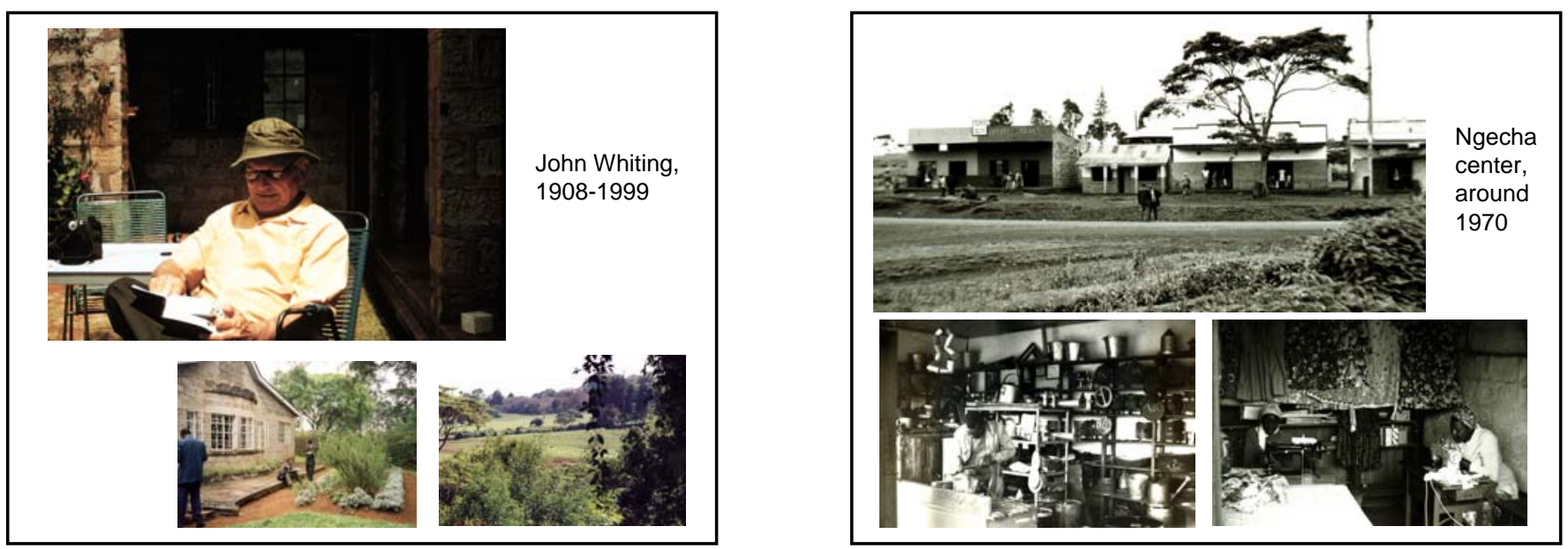

Many large homesteads contained both traditional, round, mud-and-wattle houses and modern wooden square types.
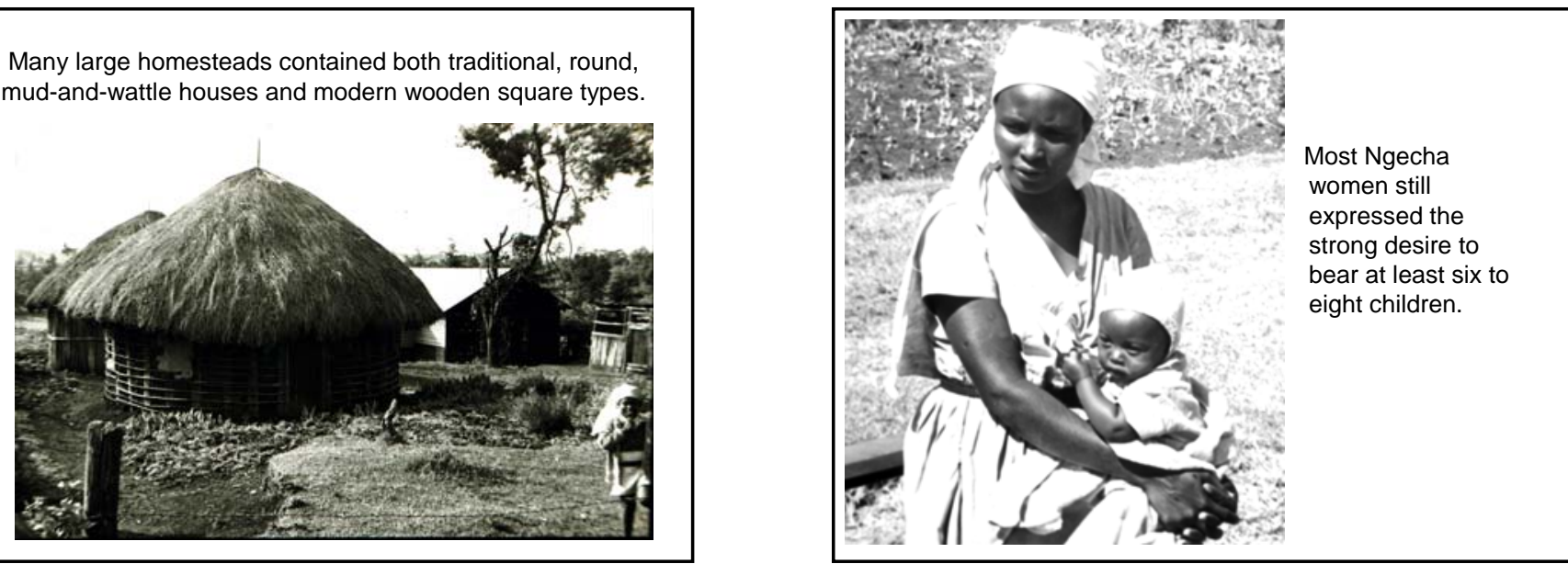

Children ran off to preschool or primary after breakfast.

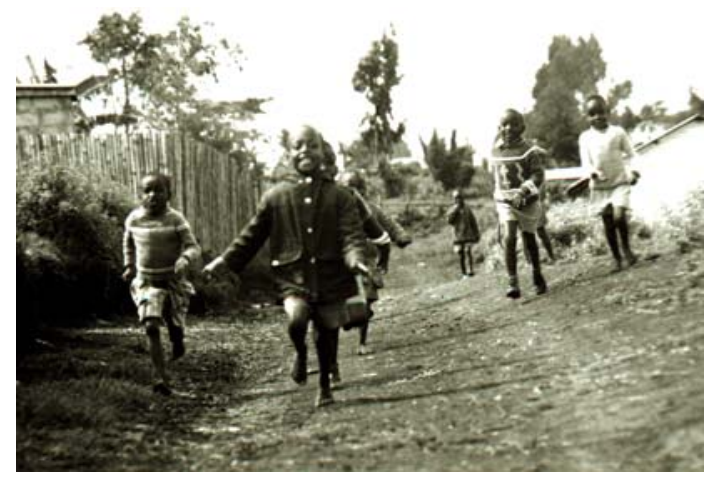


The nursery school teacher often led circle games and songs with the large, multi-aged group of children not yet old enough or financially able to go to primary school.

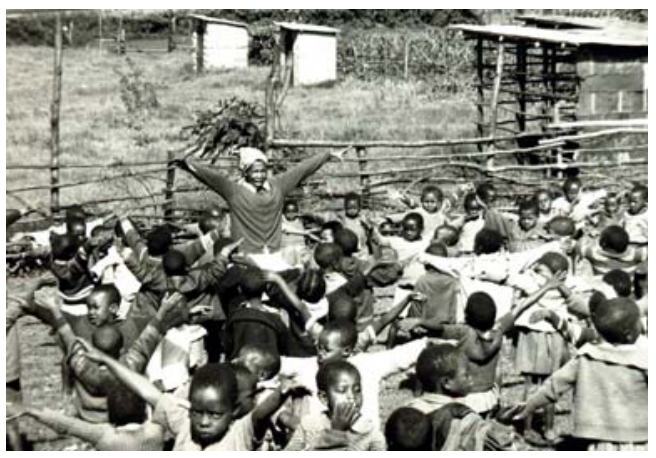

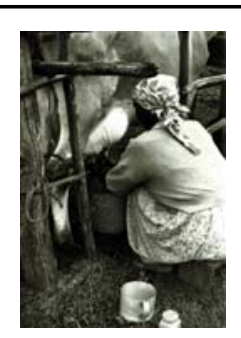

During the day, women milked, cut fuel, and gathered fodder for the cow

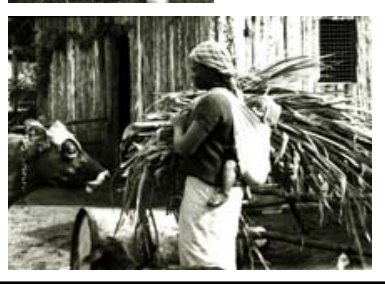

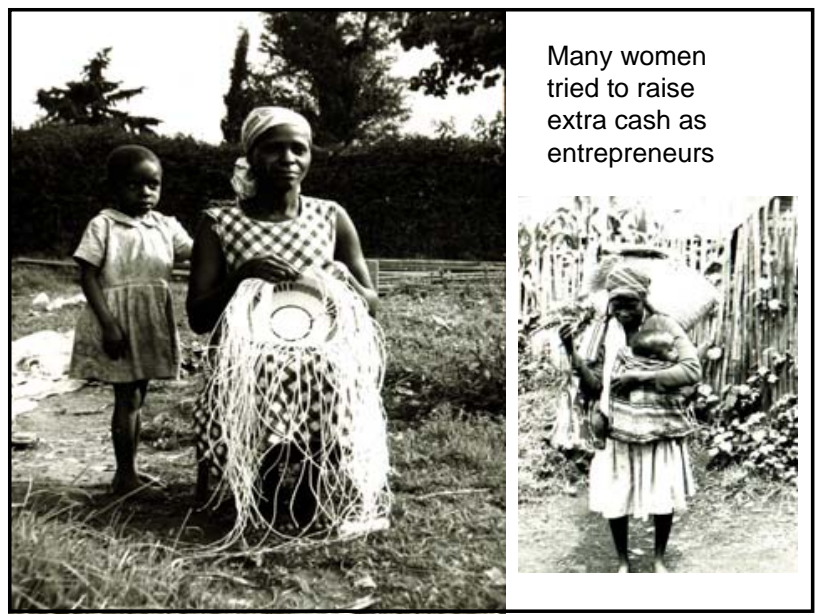

Children were socialized to traditional values of hard work and responsibility through chores. Many girls aged 6-10 years served as nurses to their younger siblings. Boys would also do the job if no girl of the right age was available.

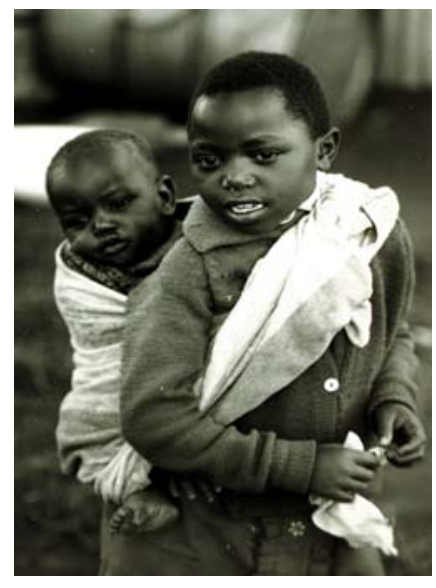

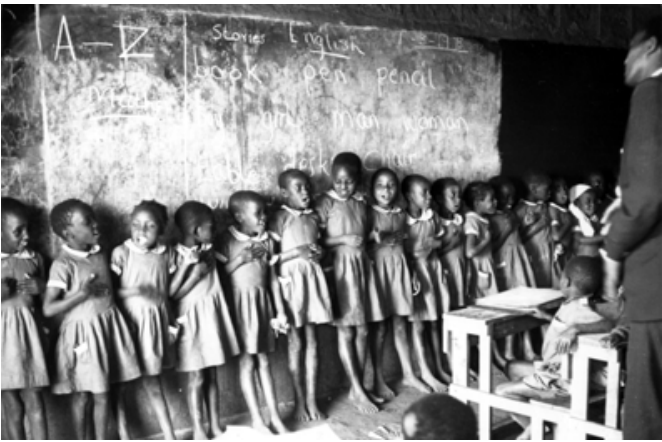

Ngecha schools in 1968-1973 did not have a strong success rate of sending children on to upper levels of secondary school and university education.
Children helped with all of the agricultural tasks of weeding and harvesting. Here they help dry pyrethrum, a cash crop.

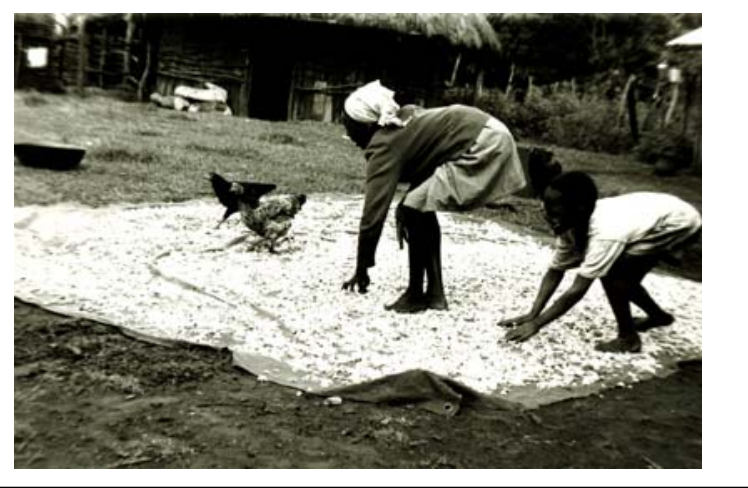



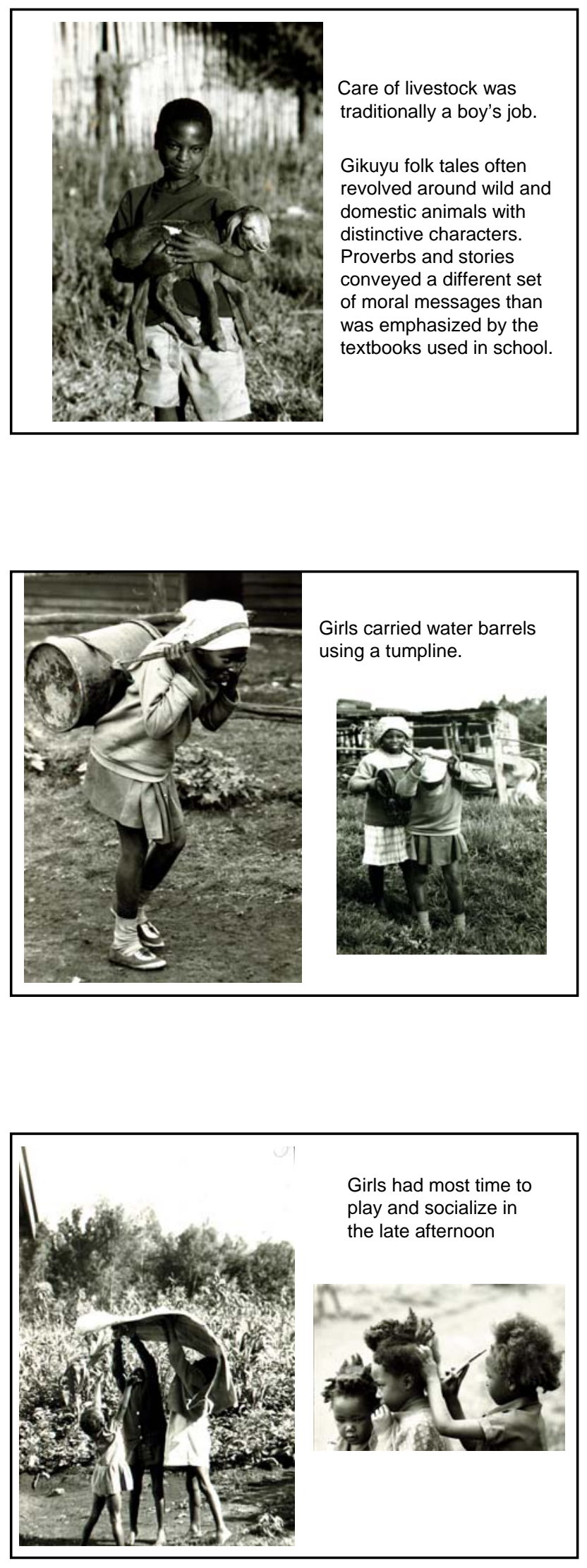

Girls learned the skills of cooperation through years of working closely together with their mothers and sisters.

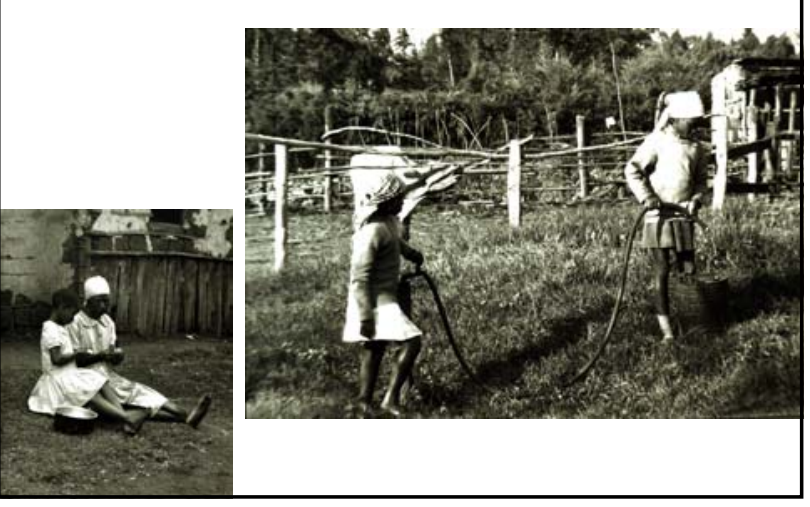

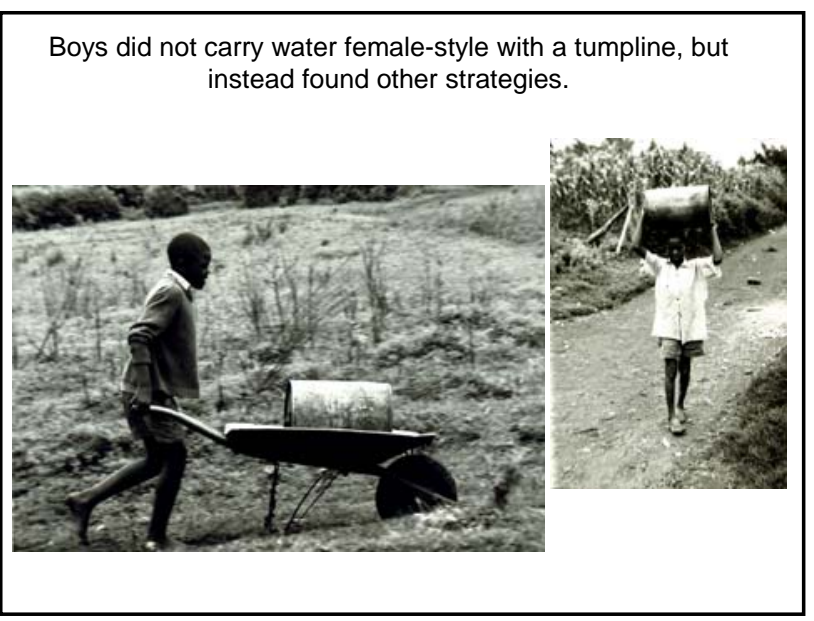

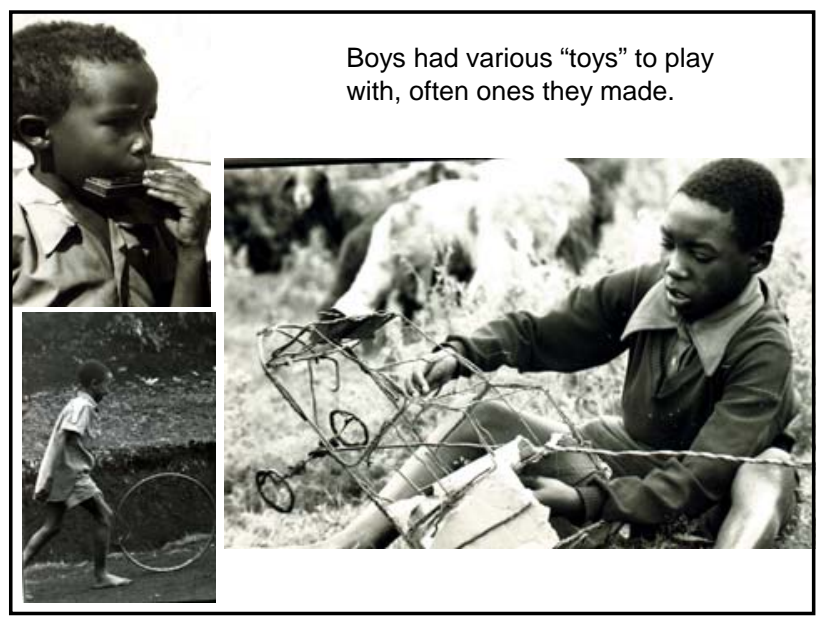


The mother prepared the evening meal, usually consisting of mashed vegetables, as the older children headed home.

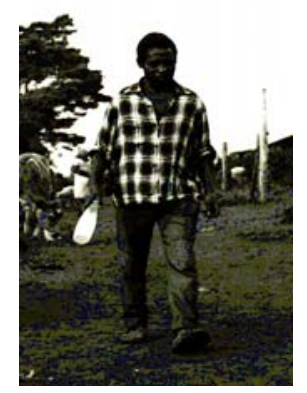

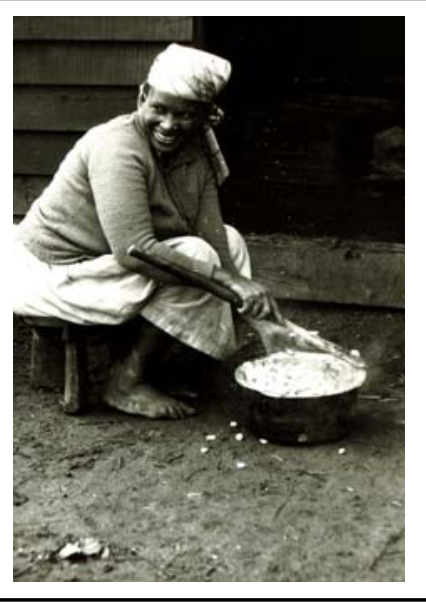

Relations between the sexes were changing as young people gained more autonomy from parental control and were more likely to live in nuclear households.
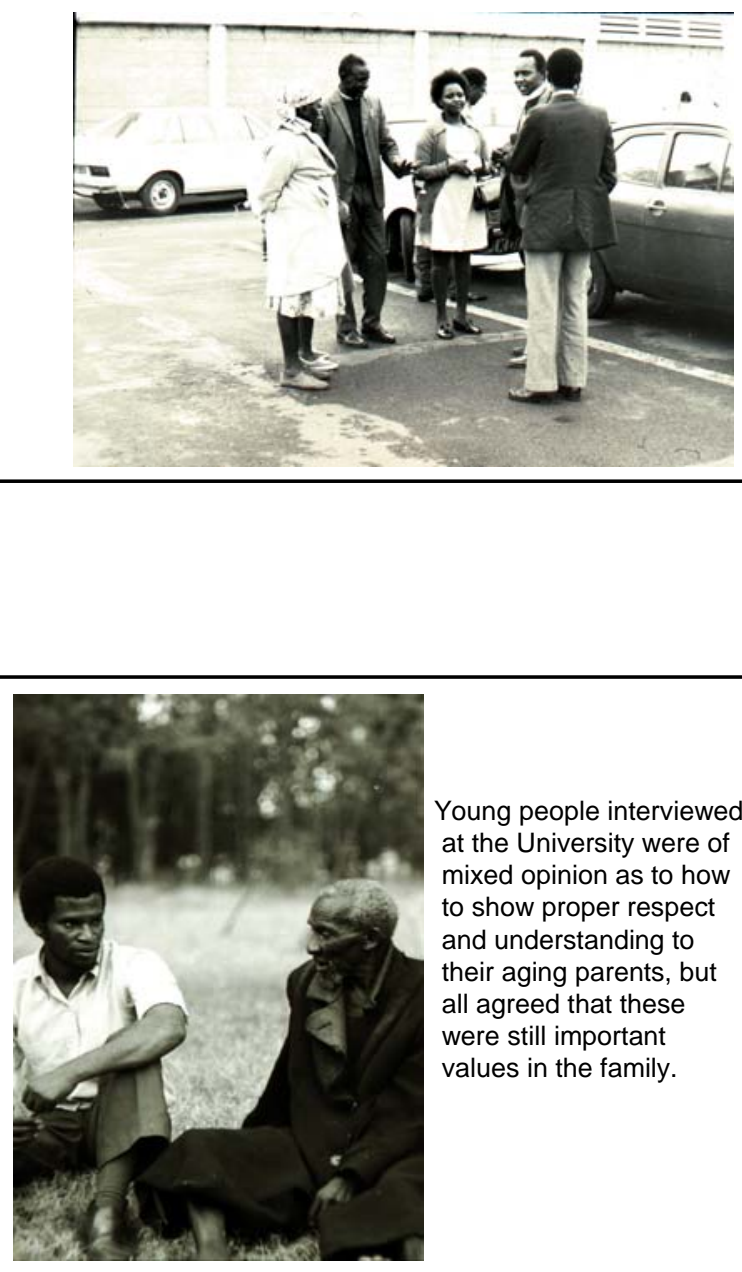

Young people interviewed at the University were of mixed opinion as to how to show proper respect and understanding to their aging parents, but all agreed that these were still important values in the family.
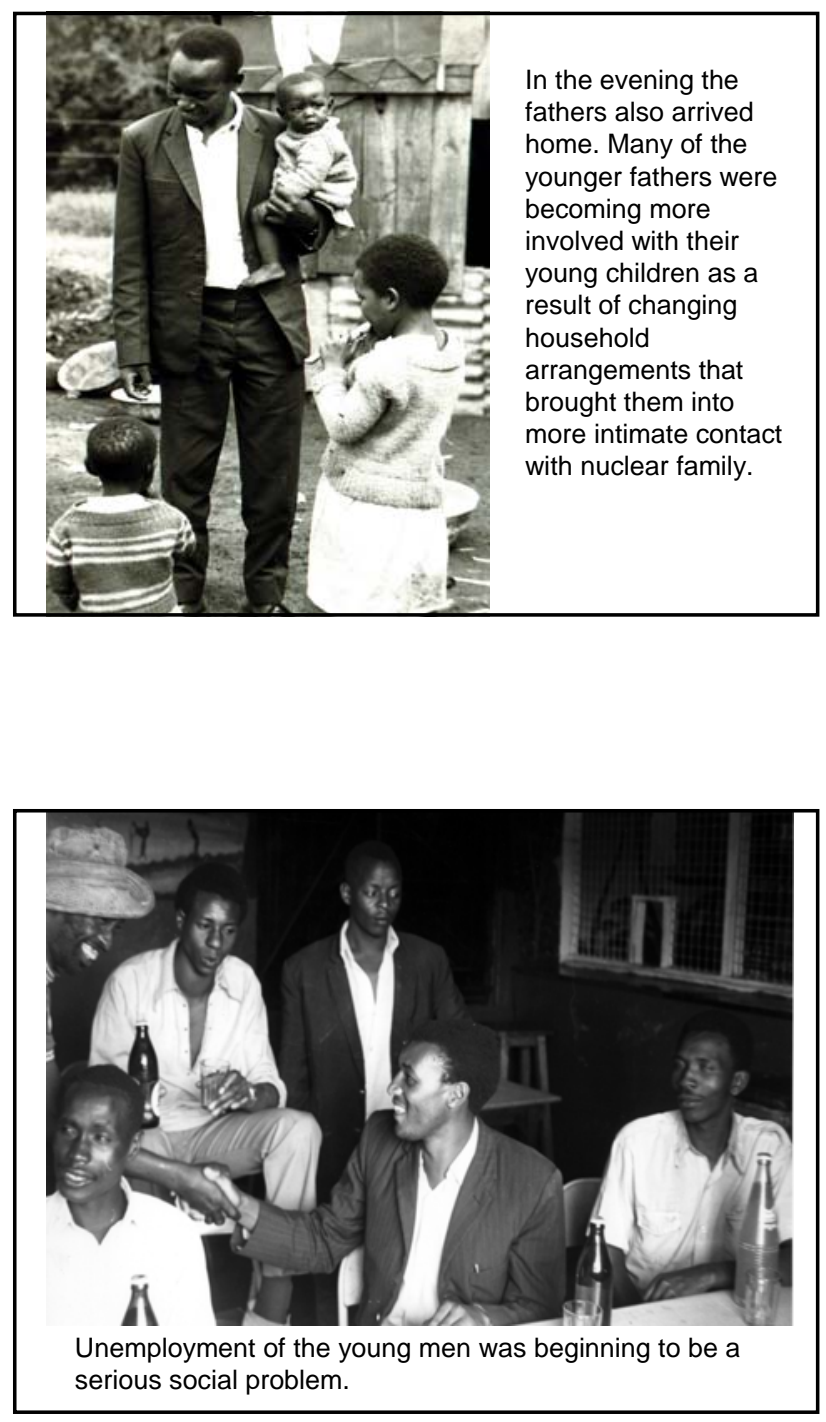

People desired to grow old in their own homes, adequately provided for by their offspring.

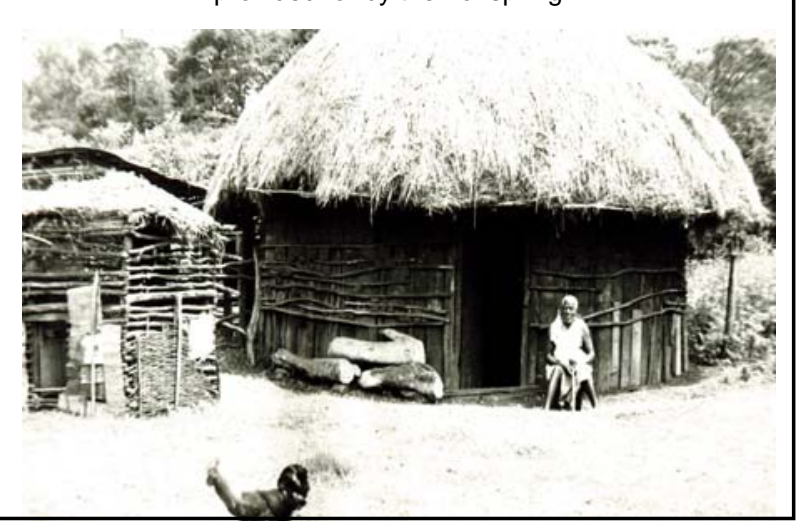



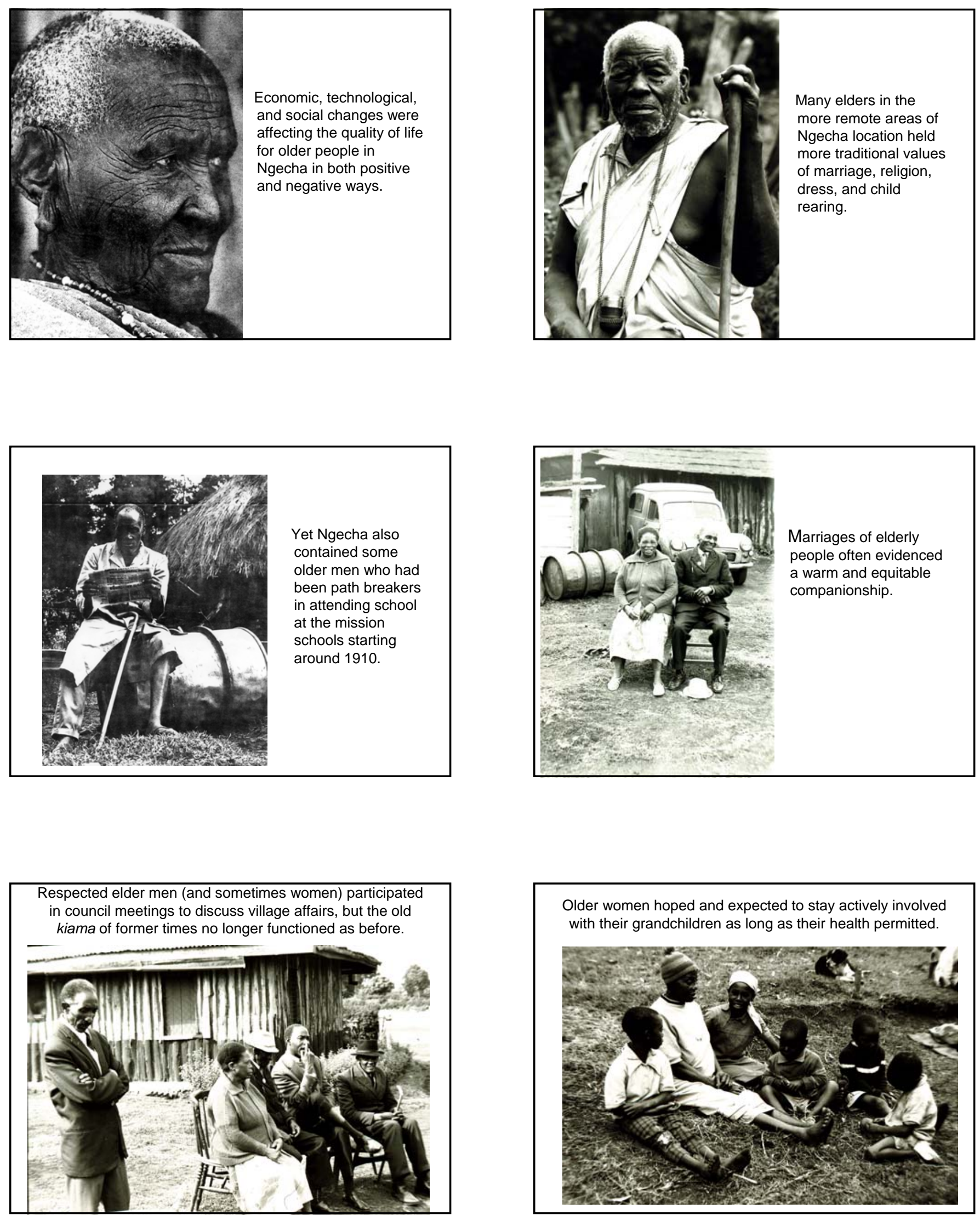


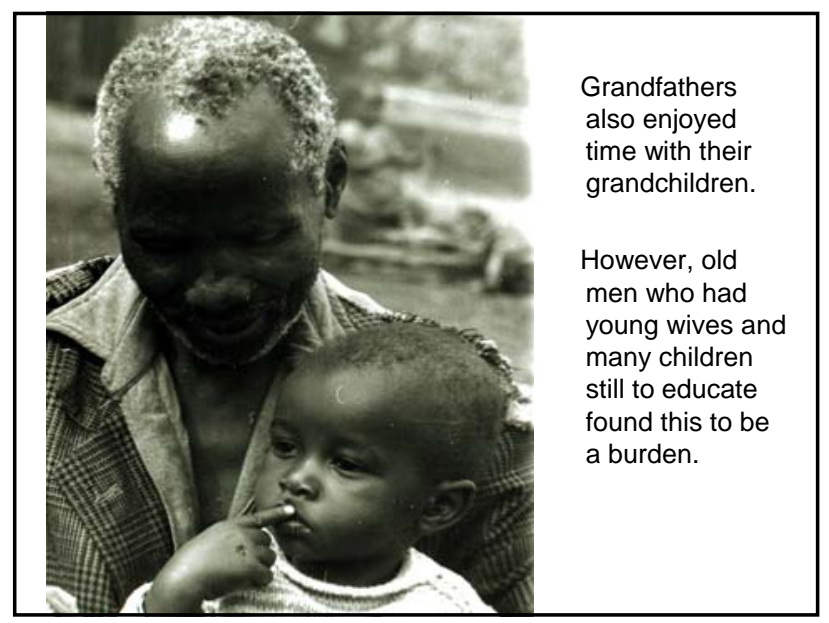

Some women who were part of the original study in 1968 to 1973 participated in a focus group discussion led by Professor Kimani (far right).

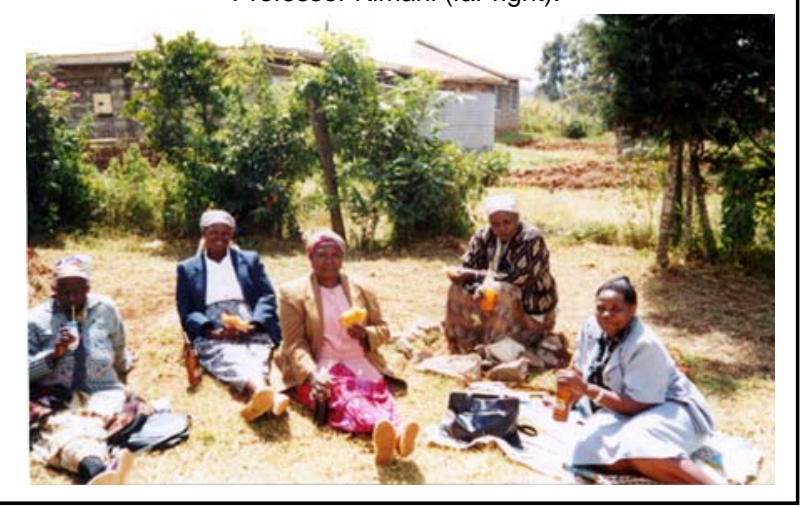

Most houses today are built with iron sheet roofing and timber walls, but in the background is seen a rarer, more expensive house built of stone walls and tile roofing.

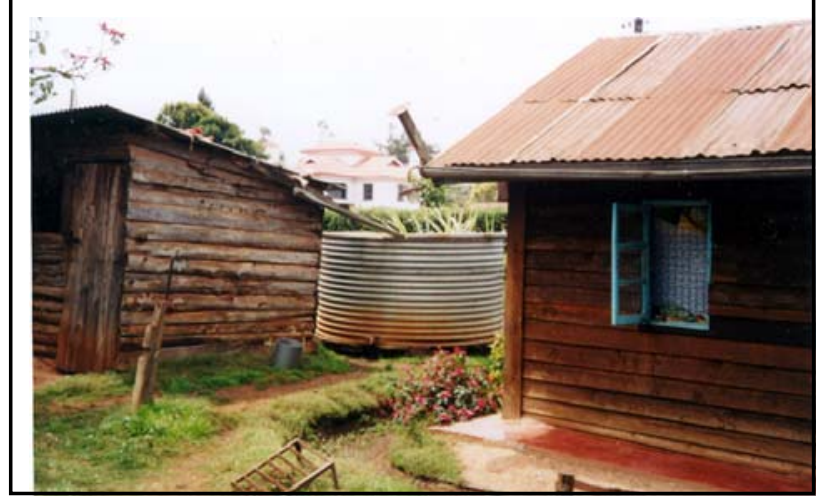

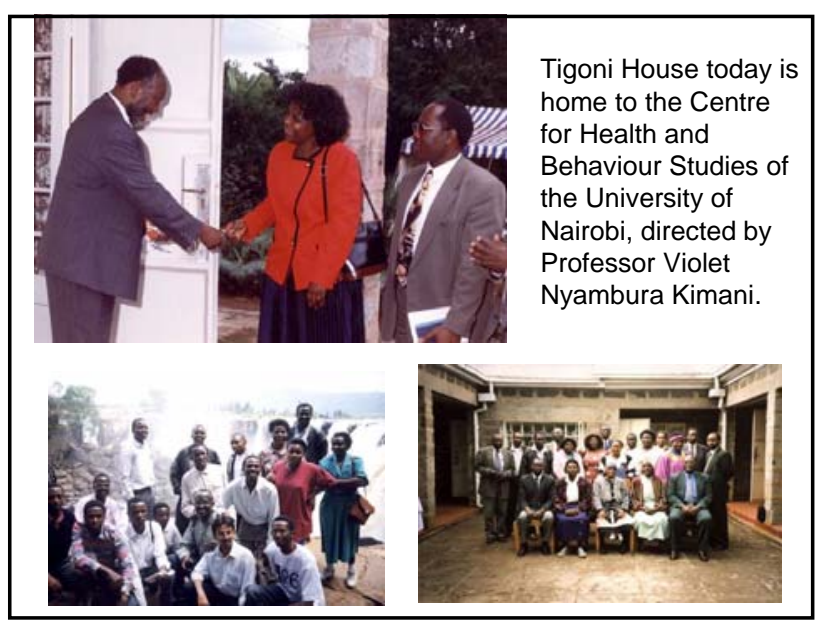
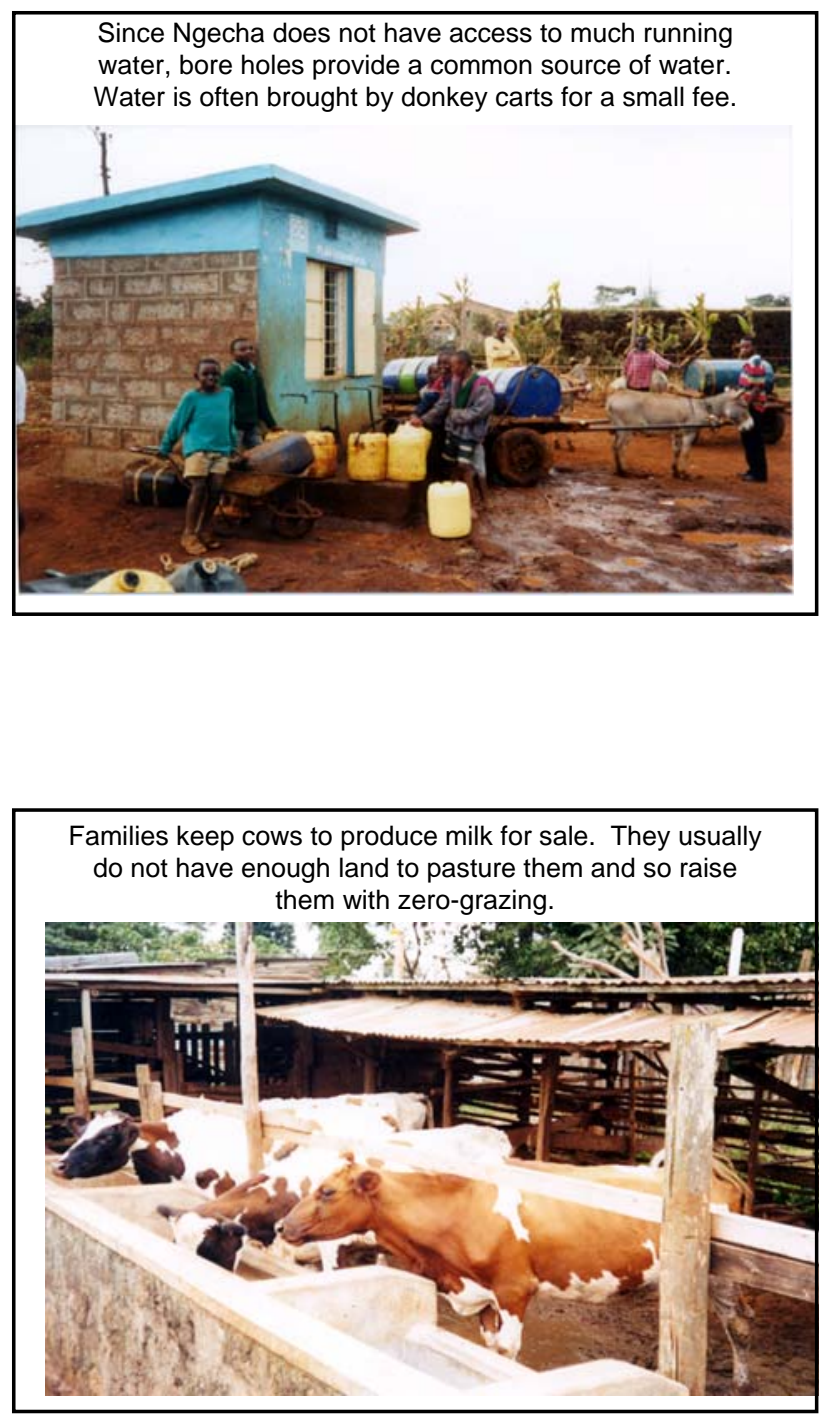

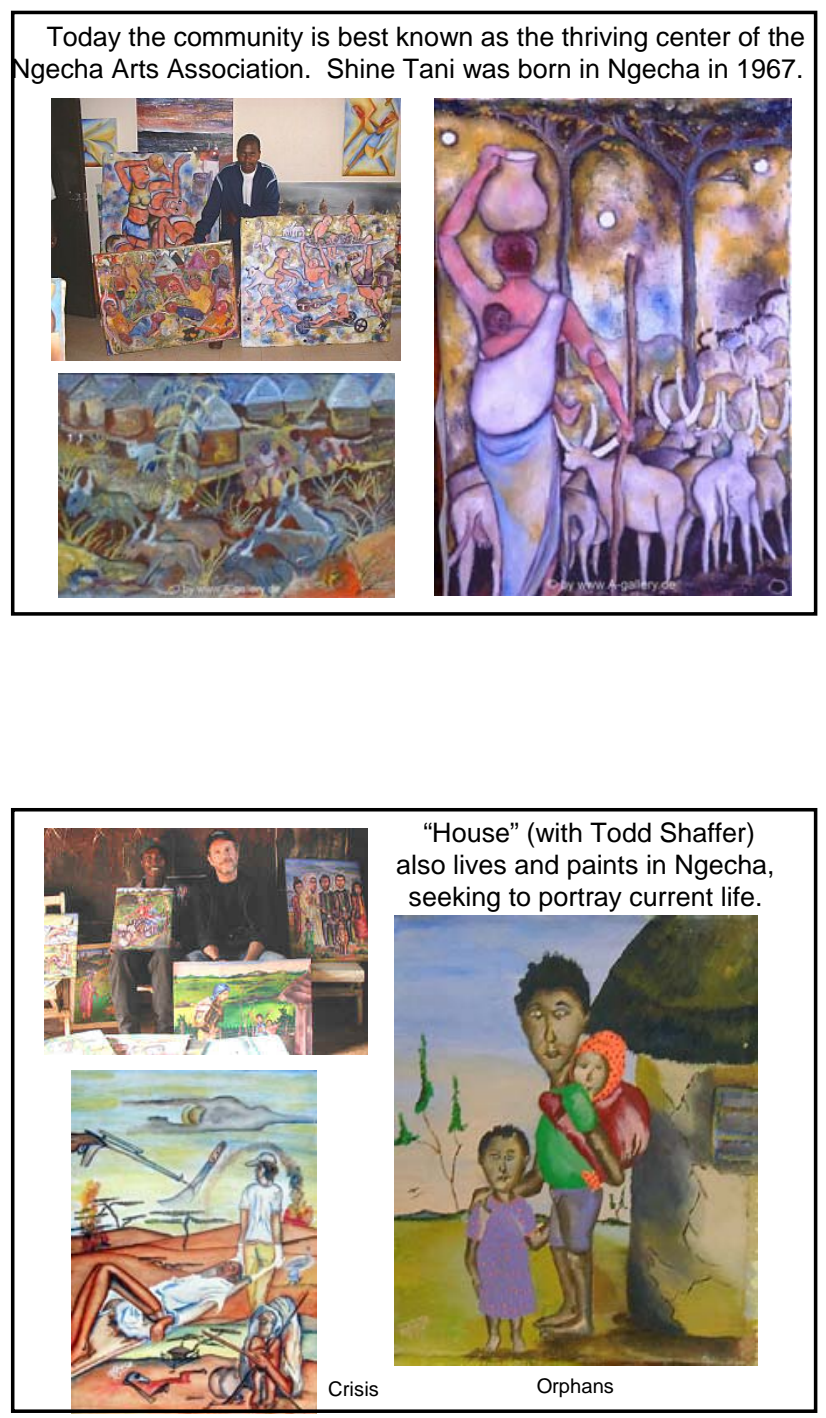

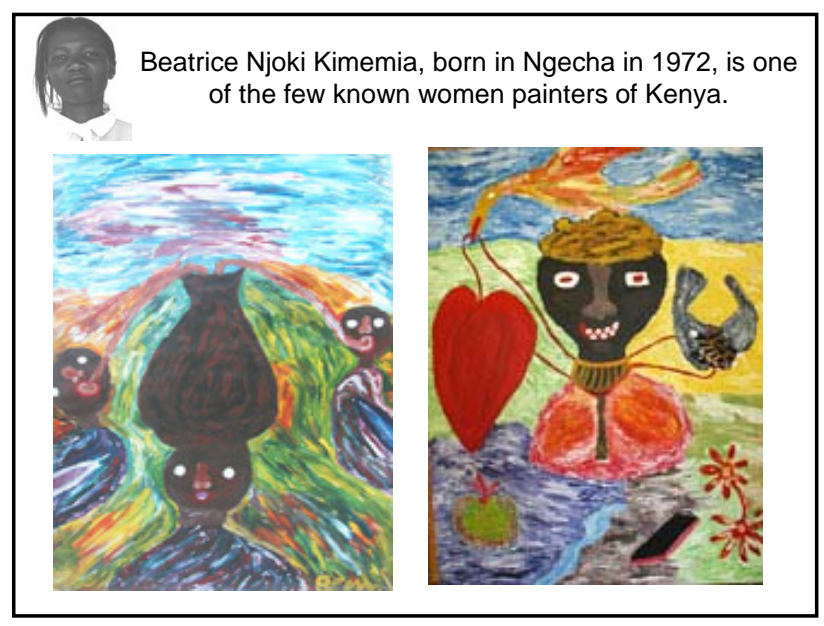

\section{Photo Credits}

- Frances Cox

- Violet Nyambura Kimani

- Sayre Sheldon

- Carolyn Edwards

- Todd Shaffer, of www.InsideAfricanArt.com 